\title{
Categorization and geovisualization of climate change strategies using an open-access WebGIS tool
}

\author{
Emőke Kiss, Marianna Zichar, István Fazekas, Gergő Karancsi, and Dániel Balla
}

\begin{abstract}
The focus of our paper is to present the power of collaboration of databases in a web environment, where data contain or are related to different types of social geography spatial data. Implementing different data gained from the Climate Change Laws of the World, the United Nations Treaty Collection, the World Bank and The World Factbook, we ourselves developed the Climate Change Strategies of the world's countries (called CCS). Our purpose is to publish and demonstrate the spatial visualization and categorization of the climate change strategies (CCS) of the world's countries, and also highlight the power of geovisualization in terms of cognitive InfoCommunications, using open-access WebGIS tools and geoinformatics software. The evolved geographic database is able to provide information for users about the different types of climate change strategies of the world's countries in a visual way, but can also be extended by uploading new data.
\end{abstract}

Index Terms-adaptation, CogInfoCom, GIS, mitigation, webmap

\section{INTRODUCTION}

$\mathrm{T}$ The increasing demand for information in today's society has meant that the scientific community has published their results on the web during the last two decades, adapting to national and international requirements. Due to the rapid expansion of the Internet and the development of web-based or regional spatial information systems, access to spatial data on various themes and of varying quality has become significantly easier. As a result of the data harmonization of national and international databases, these robust systems are available for everyone, making accessible the knowledge stored in databases. In the age of the information society, the web is an unavoidable platform for efficient and fast data sharing, be it public or private. The tools provided by the web unwittingly offer us a development trajectory with regards to transmitting information. The possibilities offered by the world wide web increase the available data regarding geographical locations in two ways. Different applications provide various possibilities in many forms for publishing research results. Furthermore, the appearance of online map services has significantly altered the interpretation and visualization of geographical data on the web.

The concept of visualization of spatial data appeared as early as the 1950s in the cartography literature of the United States [1]; however, it received more attention only during the

Correspondence: zichar.marianna@inf.unideb.hu 1980s when researchers from different fields started to focus on the potential applications of scientific visualization [2-4]. As McCormick et al phrased it, the goal of scientific visualization is the graphical demonstration of the data collected by researchers, which helps the interpretation of the information coded in the data [5]. Naturally, visualization applied in the scientific field is not limited to spatial data - it is used in several other fields, as well (e.g. diagnostic imaging, $3 \mathrm{D}$ visualization of molecules, 3D printing etc.). Other concepts which are strongly related to scientific visualization are information visualization and geovisualization (data related to spatial location). Information visualization mostly revolves around interactive demonstration and thereby helps human cognition. However, scientific and information visualization is different from geovisualization since its goal is to develop demonstration methods for spatial data using maps [6]. MacEachren coined the word geovisualization by contracting the expression "geographic visualization"; its essence is a new approach to the use of maps. One of its features is that a map is not created for the public but for individual use and its primary purpose is to provide new insights from the data. It supposes an intensive interaction between people and maps in the sense that we can directly manipulate the spatial data to be mapped. If we are talking about visualization, we do not use maps alone, but in combination with other visual aids (charts, tables, photographs, 3D models etc.) [7]. In this sense visualization and communication are complementary events during map use. It is the responsibility of the map user to decide whether the visualization or the communication aspect should be emphasized [8].

The complexity of the term cognitive InfoCommunications (CogInfoCom) closely reflects its multidisciplinary characteristics. According to its first and still the most relevant definition, it "explores the link between the research areas of InfoCommunications and cognitive sciences, as well as the various engineering applications which have emerged as a synergic combination of these sciences" [9-10]. Since the birth of this special field it has already become known in many disciplines, as is proved by several scientific papers containing sections examining the cognitive aspects of the results, as well. Due to this increased interest, a comprehensive overview of cognitive InfoCommunications is already available in the form of a book, which also provides an outstanding theoretical foundation for the topic [11-29]. 
Based on the above, our purpose is to publish and demonstrate the spatial visualization and classification of the climate change strategies (CCS) of the countries of the world, and also highlight the power of geovisualization in terms of cognitive infocommunication, using open-access webGIS tools and geoinformatics software.

\section{MATERIAL AND METHODS}

\section{A. Background to the classification of CCS according to global databases}

Climate change is caused by the excessive amount of anthropogenic greenhouse gases emitted into the atmosphere, leading to the constant increase of the global mean temperature [30]. The phenomenon first received attention from the scientific community at the end of the 1980s; today is the most urgent global problem [31-36]. Since then, the number of publications written in the subject has been constantly increasing, and global, national and subnational level databases have been created to foster the spread of information.

\section{B. Climate Change Laws of the World}

The Grantham Research Institute on Climate Change and the Environment (GRI) and the Columbia Law School Sabin Center on Climate Change Law (SCCC) together established the Climate Change Laws of the World online database which is a freely accessible resource for the policies and laws of countries related to climate change and environmental protection [37].

The GRI is a research institute founded in 2008 by the London School of Economics and Political Science. It aims to publish information internationally on climate change and environmental protection which are relevant to policies.

The goal of SCCC is to develop legal methods to combat climate change and to publish up-to-date information about climate change regulations.

\section{United Nations Treaty Collection}

The United Nations (UN) is an international organization working to solve problems concerning humanity (climate change, sustainable development, safety, peace, human rights, terrorism, food safety etc.). The UN also has several specialized organizations. For the development of our database, we used the information regarding the legally binding documents related to climate change (United Nations Framework Convention on Climate Change, Kyoto Protocol, Paris Agreement) [38].

\section{World Bank}

The World Bank Group is a global institution whose primary objective is to achieve the prosperity of developing countries and diminish poverty, as well as foster sustainable development. The organization publishes open-access and free statistical data in which searches can be performed by countries or indicators. In our database we used the Total population table from which we extracted the population data from 2017 [39].

\section{E. The World Factbook}

The World Factbook is an online, freely accessible up-todate database compiled by the Central Intelligence Agency (CIA) providing information on the countries of the world. For our database, we used the Government type data from the Government database of the countries. [40].

\section{F. Climate Change Strategies of the World countries (CCS)}

For the compilation of our CCS database, we first selected the documents related to climate change from the Climate Change Laws of the World data by country. Then we grouped the documents according to the fields they applied to, thus creating the following types: 1. Adaptation, 2. Mitigation, 3. Complex (adaptation and mitigation goals in one document). After this grouping, we listed the types associated with the countries and established categories: 1. Adaptation, 2. Mitigation, 3. Complex, 4. Partial adaptation, and 5. Partial complex documents. In the case of partial documents, the contents of the documents apply to a certain subfield, such as agricultural adaptation, energy economics adaptation and mitigation etc. If, for a certain country, adaptation and mitigation documents could be found, we named the category adaptation + mitigation. In practice, 14 potential categories can be distinguished.

As a second step, we connected our database to the data of World Bank Population, then the United Nations Treaty Collection data, and finally the Factbook Government type, thereby creating our own database, named Climate Change Strategies of the World's Countries (CCS).

\section{G. Data mining and geoprocessing}

The implementation itself has three main stages (Fig. 1). We collected data from the Climate Change Laws of the World, the United Nations Treaty Collection, the World Bank and The World Factbook web platforms. The geodatabase containing the boundaries of countries was downloaded as a vector file (.shp) from EUROSTAT. The classification made on the basis of the previous section created arrays containing climate change strategy in fourteen classes. During the geoprocessing, we added related attributes data from the EUROSTAT database to the created Climate Change Strategies (CCS) database by spatial location. Following this, the next step was geoinformatics processing using QGIS 3.6 software. We used the QGIS QGIS2Web module for geovisualizing [41]. This plugin exports the classified vector data to a map appearing in web browser. The final step was to publish the web map and data with a query interface online.

When selecting the spatial database, the main consideration was to use freely available databases containing information which users can access easily, and which can be interpreted by visualization. In this way, users can acquire more information about various climate change strategies around the world. 
Categorization and geovisualization of climate

change strategies using an open-access WebGIS tool

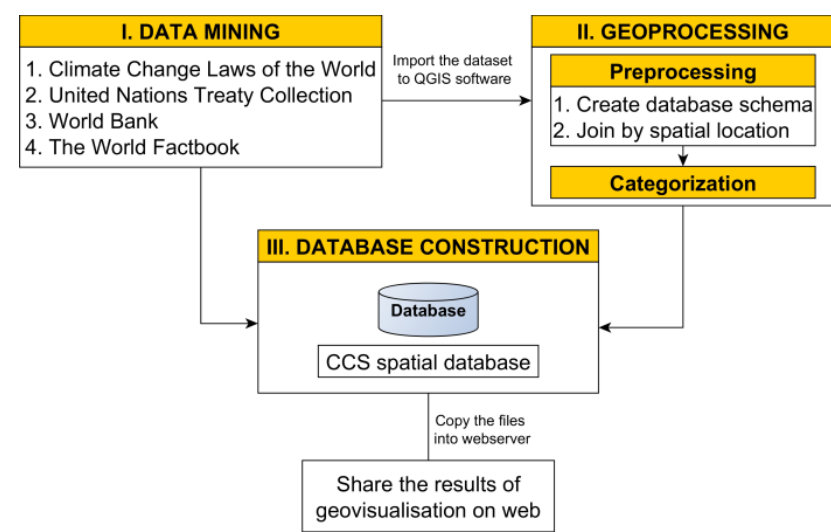

Fig. 1. Process of geovisualization.

\section{RESULTS}

We attached four databases to the CCS and made them accessible for free [42]. The classified database shows the climate change strategies of the world according to the CCS in a third-generation web map (Fig. 2). During the visualization of the climate change strategies of the world countries, we published two thematic maps (the climate change strategies categorization and the database containing the list of countries ratifying the Paris Agreement). As the default setting, the loaded web map shows the classified database which can be freely zoomed in and out, and the length of the specified routes can be calculated. In addition to navigating on the map, we can control the visibility of each layer. Furthermore, there is a Search by location function integrated into the interactive surface which we can use to navigate to the desired geographical location in the web map, thereby informing the user about the type of the climate change strategy. The visibility of the layers can also be controlled by use of the menu located in the right upper corner. Information about the CCS can be queried by clicking, and results showing the appropriate data from the attribute table are visible to users in a window and in the query interface, with descriptive statistics and charts.

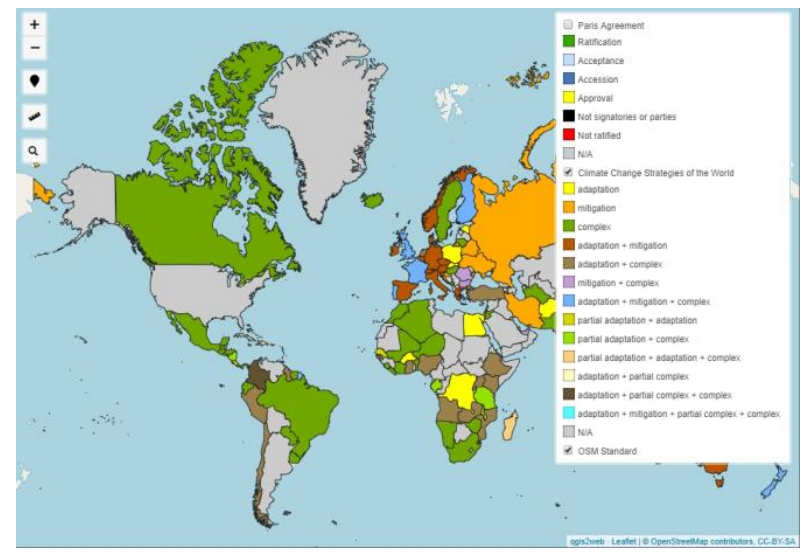

Fig. 2. Interactive webmap interface of CCS.
During our research we investigated the data of 200 countries. The national level climate change strategies tend to have three pillars: decreasing the degree of the emission of greenhouse gases (mitigation), adapting to the inevitable consequences (adaptation), and shaping public awareness to acquire the knowledge and to adopt the mentality and lifestyle necessary for achieving the above. In accordance with the above, the strategies can target mitigation or adaptation goals, or can be complex strategies in which all three areas are represented in a complementary fashion. In the case of partial strategies, the contents of the document apply only to a specific area (e.g. agricultural adaptation, energy economics adaptation and mitigation etc.).

Fig. 3 shows the distribution of documents by category. The most frequently occurring category is N/A (where no strategy can be found) with 63 countries - the proportion of countries in this category is $31.5 \%$. Of these 63 countries 24 are located in Africa. This is followed by the complex category with 47 countries, representing $23.5 \%$ of all countries. The adaptation + complex category has 29 countries, or $14.5 \%$ of all countries. The most rarely occurring three categories are the adaptation + mitigation + partial complex + complex, the adaptation + partial complex, and the adaptation + partial complex + complex, which each include 1 country. Furthermore, there are 3 countries in each of the following categories: the partial adaptation + adaptation, and partial adaptation + adaptation + complex, and 5 countries each in the mitigation + complex, and partial adaptation + complex categories.

Regarding the proportion of the world's population in each category, $32.12 \%$ (2.4 billion) and $24.11 \%$ (1.8 billion) of the population of the investigated countries can be found in the complex category and the adaptation + mitigation + complex category, respectively. The category with the lowest population (26.9 million), representing $0.36 \%$ of the entire database, is the partial adaptation + adaptation category, while the mitigation + complex category has $0.61 \%$ of the population (45.6 million). It should be emphasized that $12.05 \%$ (i.e. 902 million people) of the world's population live in investigated countries which do not have any strategies at all (N/A). This highlights the fact that even though climate change is a serious global problem, in several countries appropriate methods have not been developed, neither for mitigation nor adaptation. According to prognoses, the impacts of climate change will continue to increase, therefore it is likely that the number of strategies will grow, and more and more countries will compile their own strategies.

The most recent milestone of global climate policy is the Paris Agreement, which was accepted at the Conference of the Parties (COP 21) to the United Nations Framework Convention on Climate Change (UNFCCC) and came into effect on November 04, 2016. The Paris Agreement is a legally binding, internationally harmonized framework to arrest climate change, but it does not include obligatory regulations. It aims to prevent the global mean temperature from exceeding the $+2{ }^{\circ} \mathrm{C}$ considered to be an irreversible 
Categorization and geovisualization of climate

change strategies using an open-access WebGIS tool turning point relative to the pre-industrial era, and to achieve control even with a $+1.5^{\circ} \mathrm{C}$ increase [43]. Of the investigated countries, the Agreement was ratified by 114 countries in 2016 and further 48 countries in 2017. In 2018 and 201910 and 1 additional countries also signed the Agreement, respectively. Therefore, by 2019173 of the investigated countries had ratified, and 13 countries had not ratified the Agreement (Fig. 4). Furthermore 6 countries had Acceptance, 3 countries had Approval, and 2 countries had Accession status. The Vatican is not a signatory nor a party to the UNFCCC and for 2 countries there were no data available (Antarctic, Western Sahara).
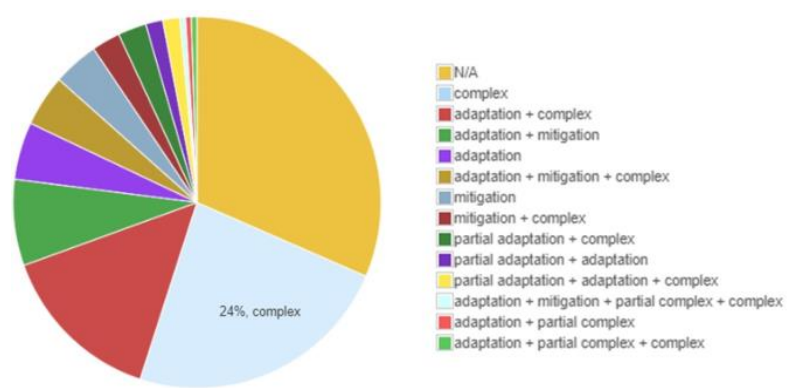

Fig. 3. Distribution of the CCS categories in percentages (\%) based on the database.
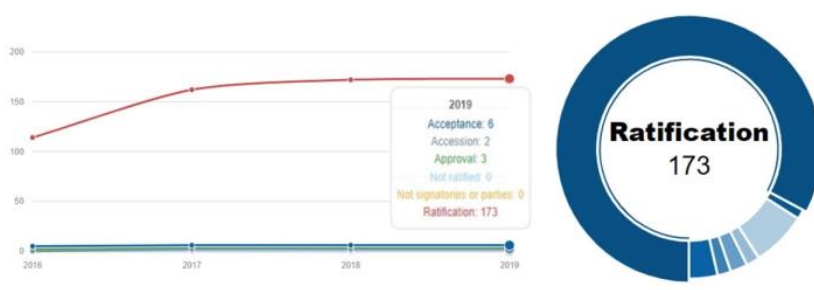

Fig. 4. Status types of the Paris Agreement.

\section{COGNITIVE ASPECTS OF THE STUdY}

The goal of this paper is to study how cognitive processes co-evolve with interactively based infocommunication GIS tools, while the human brain is extended through these devices and also interacts with various artificial cognitive systems. In this context our paper focuses on the benefits of the geovisualization of spatial data in terms of cognitive infocommunications. These benefits are: easier identification of the relationship between climate change strategies and their location, easier capture of spatial pattern and types of CCS related documents, and also support for the cognitive perception of the digitally stored data.

\section{CONCLUSION}

In conclusion, we can state that use of free data makes it possible to publish geospatial information by applying the QGIS QGIS2Web module. Nevertheless, we have to pay attention to questions of whether the data are up to date and reliable when selecting which data to use. The global databases used are representative in themselves; however, by combining these databases and applying the categorization method we developed, we were able to assess climate change strategies and their spatial configuration from a new perspective.

\section{ACKNOWLEDGMENT}

This work was supported by the construction EFOP-3.6.3VEKOP-16-2017-00002. The project was supported by the European Union, co-financed by the European Social Fund.

\section{REFERENCES}

[1] A. K. Philbrick, "Toward a unity of cartographical forms and geographical content," Professional Geographer, vol. 5, no. 5, pp. 11-15, Sept. 1953. DoI: 10.1111/j.0033-0124.1953.55_11.x.

[2] D. R.F. Taylor, "Geographic Information Systems: the microcomputer and modern cartography," in Geographic Information Systems: The Microcomputer and Modern Cartography, D.R.F. Taylor, A.M. MacEachren, Eds. Great Britain, Oxford, Pergamon. 1994, pp. 333342 .

[3] A. M. MacEachren, M. J. Kraak, "Exploratory cartographic visualization: advancing the agenda," Computers \& Geosciences, vol. 23, no. 4, pp. 335-343, May. 1997. DoI: 10.1016/S0098-3004(97)00018-6.

[4] K. C. Stuart, J. D. Mackinlay, B. Shneidermann, Reading in information visualization: using vision to think. San Francisco, CA, USA: Morgan Kaumann Publishers, 1999, pp. 1-712.

[5] B. H. McCormick, T. A. DeFanti, M.D. Brown, Eds. "Visualization in Scientific Computing," Computer Graphics, vol. 21, no. 6, pp. 1-63, 1987.

[6] T. Munzner, "Process and Pitfalls in Writing Information Visualization Research Papers," in Information Visualization. Lecture Notes in Computer Science, vol. 4950, A. Kerren, J.T. Stasko, JD. Fekete, C. North Ed. Berlin, Heidelberg: Springer, 2008, pp. 134-153.

[7] A. M. MacEachren, M. Gahegan, W. Pike, I. Brewer, G. Cai, E. Lengerich, and F. Hardisty, "Geovisualization for knowledge construction and decision-support," IEEE Computer Graphics \& Applications, vol. 24, no. 1, pp. 13-17, Jan.-Feb. 2004. DoI: 10.1109/MCG.2004.1255801.

[8] A. Pődör, M. Kiszely, "Experimental investigation of visualization methods of earthquake catalogue maps," Geodesy and Cartography, vol. 40, no. 4, pp. 156-162, Dec. 2014. DOI: $10.3846 / 20296991.2014 .987451$.

[9] P. Baranyi, Á. Csapó, "Definition and synergies of cognitive infocommunications," Acta Polytechnica Hungarica, vol. 9, no. 1, pp. 67-83, 2012.

[10] P. Baranyi, Á. Csapó, Gy. Sallai, Cognitive Infocommunications (CogInfoCom). Berlin, Heidelberg, Springer: 2015, pp. 1-219. DoI: 10.1007/978-3-319-19608-4.

[11] J. Katona, A. Kovari, "Examining the Learning Efficiency by a BrainComputer Interface System," Acta Polytechnica Hungarica, vol. 15, no. 3, pp. 251-280, 2018.

[12] J. Katona, A. Kovari, "The Evaluation of BCI and PEBL-based Attention Tests," Acta Polytechnica Hungarica, vol. 15, no. 3, pp. 225-249, 2018.

[13] P. Bőczén-Rumbach, "Industry-Oriented Enhancement of Information Management Systems at AUDI Hungaria using MaxWhere's 3D Digital Environments," in 9th IEEE International Conference on Cognitive Infocommunications (CogInfoCom), Budapest, Hungary, 2018, pp. 000417-000422. DoI: 10.1109/CogInfoCom.2018.8639959. 
Categorization and geovisualization of climate

change strategies using an open-access WebGIS tool
[14] V. Bochicchio, C. Scandurra, R. Vitelli, P. Valerio, S. dell'Orco, and N. M. Maldonato, "Epistemology of Olfaction: Emotion, Cognition, and Decision Making," in 9th IEEE International Conference on Cognitive Infocommunications (CogInfoCom), Budapest, Hungary, 2018, pp. 000267-000270. DoI: 10.1109/CogInfoCom.2018.8639940.

[15] D. Sik, K. Csorba, P. Ekler, "Toward Cognitive Data Analysis with Big Data Environment," in 9th IEEE International Conference on Cognitive Infocommunications (CogInfoCom), Budapest, Hungary, 2018, pp. 000023-000028. DoI: 10.1109/CogInfoCom.2018.8639948.

[16] S. Korecko, M. Hudák, B. Sobota, M. Marko, B. Cimrová, I. Farkaš, and R. Rosipal, "Assessment and training of visuospatial cognitive functions in virtual reality: proposal and perspective," in 9th IEEE International Conference on Cognitive Infocommunications (CogInfoCom), Budapest, Hungary, 2018, pp. 000039-000044. DoI: 10.1109/CogInfoCom.2018.8639958.

[17] D. Balla, T. Mester, Á. Botos, T. J. Novák, M. Zichar, J. Rásó, and A. Karika, "Possibilities of spatial data visualization with web technologies for cognitive interpretation," in 8th IEEE International Conference on Cognitive Infocommunications (CogInfoCom), Debrecen, Hungary, 2017, pp. 000017-000020. DoI: $10.1109 / \operatorname{Cog}$ InfoCom.2017.8268209.

[18] D. Sik, K. Csorba, P. Ekler, "Implementation of a Geographic Information System with Big Data Environment on Common Data Model," in 8th IEEE International Conference on Cognitive Infocommunications (CogInfoCom), Debrecen, Hungary, 2017, pp. 000181-000184. DoI: 10.1109/CogInfoCom.2017.8268238.

[19] Gy. Papp, I. Papp, R. Kunkli, "Three-dimensional connection visualization based on tabular data," in 8th IEEE International Conference on Cognitive Infocommunications (CogInfoCom), Debrecen, Hungary, 2017, pp. 000289-000290. DoI: $10.1109 /$ CogInfoCom.2017.8268258.

[20] R. Idzikowski, K. Kluwak, T. Nowobilski, T. Zamojski, “Analysis of possibility of visualization of danger factors in the building environment based on Virtual Reality model," in 8th IEEE International Conference on Cognitive Infocommunications (CogInfoCom), Debrecen, Hungary, 2017, pp. 000363-000368. DOI: $10.1109 / \operatorname{Cog}$ InfoCom.2017.8268271.

[21] Á. Török, Zs. Gy. Török, B. Tölgyesi, "Cluttered centres: interaction between eccentricity and clutter in attracting visual attention of readers of a 16th century map," in 8th IEEE International Conference on Cognitive Infocommunications (CogInfoCom), Debrecen, Hungary, 2017, pp. 000433-000438. DoI: 10.1109/CogInfoCom.2017.8268285.

[22] J. Katona, T. Ujbanyi, G. Sziladi, A. Kovari, "Examine the Effect of Different Web-based Media on Human BrainWaves," in 8th IEEE International Conference on Cognitive Infocommunications (CogInfoCom), Debrecen, Hungary, 2017, pp. 000407-000412. DoI: $10.1109 / \operatorname{Cog}$ InfoCom.2017.8268280

[23] V. Niskanen, A. Minzoni, E. Mounoud, "A Case Study on TimeInterval Fuzzy Cognitive Maps in a Complex Organization," in 8th IEEE International Conference on Cognitive Infocommunications (CogInfoCom), Debrecen, Hungary, 2017, pp. 000027-000032. DoI: $10.1109 / \operatorname{Cog}$ InfoCom.2017.8268211.

[24] E. H. Magnusdottir, K. R. Johannsdottir, C. Bean, B. Olafsson, J. Gudnason, "Cognitive workload classification using cardiovascular measures and dynamic features," in 8th IEEE International Conference on Cognitive Infocommunications (CogInfoCom), Debrecen, Hungary, 2017, pp. 000351-000356. DoI: 10.1109/CogInfoCom.2017.8268269.

[25] A. Csapo, A. Kristjansson, H. Nagy, Gy. Wersenyi, "Evaluation of Human-Myo Gesture Control Capabilities in Continuous Search and Select Operations," in 7th IEEE International Conference on Cognitive Infocommunications (CogInfoCom), Wroclaw, Poland, 2016, pp. 000415-000420. DoI: 10.1109/CogInfoCom.2016.7804585.
[26] D. Balla, M. Zichar, N. Barkóczi, O. G. Varga, "Cognitive interpretation of different spatial databases in web environment," in 6th IEEE International Conference on Cognitive Infocommunications (CogInfoCom), Györ, Hungary, 2015, pp. 159-162. DoI: 10.1109/CogInfoCom.2015.7390582.

[27] J. Katona, A. Kovari, “A Brain-Computer Interface Project Applied in Computer Engineering," IEEE Transactions on Education, vol. 59, no. 4, pp. 319-326, Nov. 2016. DoI: 10.1109/TE.2016.2558163.

[28] J. Katona, T. Ujbanyi, G. Sziladi, A. Kovari, "Speed control of Festo Robotino mobile robot using NeuroSky MindWave EEG headset based brain-computer interface," in 7th IEEE International Conference on Cognitive Infocommunications (CogInfoCom), Wroclaw, Poland, 2016, pp. 000251-000256. DoI: 10.1109/CogInfoCom.2016.7804557.

[29] D. Balla, M. Zichar, A. Kozics, T. Mester, T. Mikita, J. Incze, T. J. Novák, "A GIS Tool to Express Soil Naturalness Grades and Geovisualization of Results on Tokaj Nagy-Hill," Acta Polytechnica Hungarica, vol. 16, no. 6, pp. 191-205, 2019 DoI: 10.12700/APH.16.6.2019.6.12.

[30] IPCC, 2014. "Climate Change 2014: Synthesis Report. Contribution of Working Groups I, II and III to the Fifth Assessment Report of the Intergovernmental Panel on Climate Change," [Core Writing Team, R.K. Pachauri and L.A. Meyer (eds.)]. IPCC, Geneva, Switzerland, $151 \mathrm{pp}$.

[31] F. N. Tonmoy, D. Rissik, J. P. Palutikof, “A three-tier risk assessment process for climate change adaptation at a local scale," Climatic Change, vol. 153, no. 4, pp. 539-557, Apr. 2019. DoI: $10.1007 / \mathrm{s} 10584-019-02367-\mathrm{z}$

[32] L. Groot, J. Swart, "Climate change control: the Lindahl solution," Mitigation and adaptation strategies for global change, vol. 23, no. 5, pp. 757-782, Jun. 2018. DOI: 10.1007/s11027-017-9758-8.

[33] C. C. Makondo, D. S. Thomas, "Climate change adaptation: Linking indigenous knowledge with western science for effective adaptation," Environmental science \& policy, vol. 88, pp. 83-91, Jun. 2018. DoI: 10.1016/j.envsci.2018.06.014.

[34] C. A. Ogunbode, C. Demski, S. B. Capstick, and R. G. Sposato, "Attribution matters: revisiting the link between extreme weather experience and climate change mitigation responses," Global Environmental Change, vol. 54, pp. 31-39, Jan. 2019. DoI: 10.1016/j.gloenvcha.2018.11.005.

[35] G. McDowell, C. Huggel, H. Frey, F. M. Wang, K. Cramer, and V. Ricciardi, "Adaptation action and research in glaciated mountain systems: Are they enough to meet the challenge of climate change?," Global Environmental Change, vol. 54, pp. 19-30, Jan. 2019. DoI: 10.1016/j.gloenvcha.2018.10.012.

[36] G. J. Nagy, C. Cabrera, G. Coronel, M. Aparicio-Effen, I. Arana, R. Lairet, and A. Villamizar, "Addressing climate adaptation in education, research and practice: the CLiVIA-network," International Journal of Climate Change Strategies and Management, vol. 9, no. 4, pp. 469-487, 2017. DoI: 10.1108/IJCCSM-04-2016-0056.

[37] Climate Change Laws of the World: http://www.lse.ac.uk/ GranthamInstitute/research-theme/governance-and-legislation/

[38] United Nations Treaty Collection: https://treaties.un.org/

[39] World Bank: https://data.worldbank.org/

[40] The World Factbook: https://www.cia.gov/library/publications/theworld-factbook/

[41] QGIS QGIS2Web module: https://www.qgistutorials.com/en/docs/ web_mapping_with_qgis 2 web.html

[42] CCS database: http://siscs.exitdebrecen.hu/CCS/index.html

[43] Paris Agreement, Paris, 12 December, 2015: https://treaties.un.org/ doc/Treaties/2016/02/20160215\%2006-03\%20PM/Ch_XXVII-7-d. pdf 
Categorization and geovisualization of climate change strategies using an open-access WebGIS tool

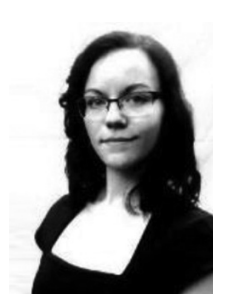

Emókke Kiss is Ph.D. student at University of Debrecen, Faculty of Science and Technology, Department of Landscape Protection and Environmental Geography, Debrecen, Hungary. Qualification is MSc in geography, University of Debrecen in 2017. Her research interests focus on climate change strategies in different levels, climate policy and geostatistical analyses.

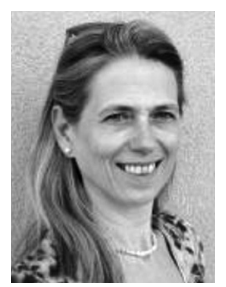

Marianna Zichar is associate professor from University of Debrecen, Faculty of Informatics, Department of Computer Graphics and Image Processing, Hungary. Worked as a software developer for 10 years after getting her MSc in mathematics and informatics. She received her Ph.D. in Mathematics and Computer Sciences and joined the staff of the Faculty of Informatics at University of Debrecen in 2005. She has participated in several multidisciplinary projects and has lectures for students of three faculties. Her research interests focus on custom application development for geographic information systems, issues in geovisualization, usage of web technologies in GIS and 3D modeling and printing.

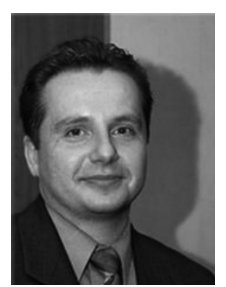

István Fazekas is senior lecturer from University of Debrecen, Faculty of Sciences, Department of Landscape Protection and Environmental Geography, Debrecen, Hungary. He received his Ph.D. in Earth Sciences and joined the staff of the Faculty of Sciences, Department of Landscape Protection and Environmental Geography at University of Debrecen in 2003. His research interests focus on waste management, environmental policy and environmental sociology.

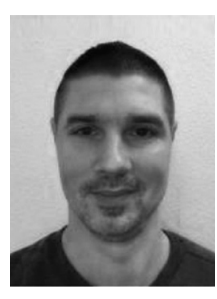

Gergó Karancsi is BSc student at University of Debrecen, Faculty of Informatics as engineer IT specialist. Qualification is MSc in geography, University of Debrecen, Hungary (2014). In focus of his research activity are geology, environmental modelling and GIS.

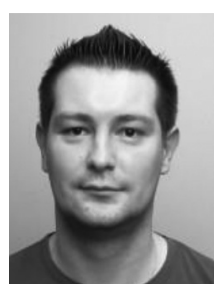

Dániel Balla is assistant lecturer from University of Debrecen, Faculty of Informatics, Department of Computer Graphics and Image Processing, Debrecen, Hungary. Qualification is MSc in geography, University of Debrecen, Hungary (2014). He studies as Ph.D. student at University of Debrecen, Faculty of Sciences, Department for Landscape Protection and Environmental Geography. In focus of his research activity are webGIS, geovisualization and soil classification. 